\title{
EFFECT OF DIFFERENT FOLIAR CONCENTRATION OF SOME BIO-STIMULATORS ON EGYPTIAN CLOVER IN CALCAREOUS SOIL.

\author{
El-Azizy, F.A.
}

Soil fertility and Microbiology Department- Desert Research Center, Cairo Egypt

Email - Fathy.el.azizy@gmail.com

Key Words: Egyptian clover, producvtity, concentration of elements, uptake of elements and calcareous soil.

\section{ABESTRACT}

A field experiment was carried out during winter season 2018 / 2019 in Maryout the agriculture experiment station of the Desert Research Center, south west Alexandria, Egypt to study the influence of foliar application of Humic acid, mixture of Amino acids and Active dry yeast and their interaction on the productivity and chemical contents of Egyptian clover (var. Meskawey) grown in calcareous soil. The experiment was planned in a split- split plot design with three replicates. The main plots were applying foliar spay of Active dry yeast include three levels $(0,2,4 \mathrm{~g} / \mathrm{L})$, the subplots included foliar spray of three levels of Humic acid ( $\mathrm{H}$ ), i.e. ( $0,2,4 \mathrm{ml} / \mathrm{L})$ and sub -sub plots was the mixture of Amino acid (A) spayed at rates ( 0,2,4 $\mathrm{ml} / \mathrm{L}$ ). Foliar spray of the studied treatments were added using four doses, first after 25 days from planting, $2^{\text {nd }}, 3^{\text {rd. }}$ and $4^{\text {th }}$ after 10 days of each cutting .

Results showed that spraying Egyptian clover 4 through times of bio stimulators active dry yeast $(4 \mathrm{~g} / \mathrm{L})$, combined with humic acid $(4 \mathrm{ml}$ $/ \mathrm{L})$ and amino acid $(4 \mathrm{ml} / \mathrm{L})$ were the most effective treatment in improving fresh and dry forage yields ton /fed, which recoded ( 46.88 and 8.52 ton / fed), respectively through the whole season and which record the highest protein \% were $15.4,18,18.2$ and $18.6 \%$ for the $1^{\text {st }}, 2^{\text {nd }}, 3^{\text {rd }}$ and the $4^{\text {th }}$ cuts, respectively. Also, this treatment recoded the highest values of nitrogen, potassium, phosphorus as concentration and uptake in the dry forage of Egyptian clover.

\section{INTRODUCTION}

Egyptian clover, or berseem, (Trifolium alexandrinum .L ), is a very important crop, for fodder and soil fertility maintenance, which was domesticated in Egypt and now is widespread in irrigated cropping systems in west and south Asia and used in commercial farming in many countries with mild winter. Foliar application technology is an integral part of root feeding which is one of the important factors in minimizing losses and rationalizing the high quantities of chemical fertilizers, as well as increasing the efficiency of the use of fertilizer that applied to the soil its direct and rapid effect, Sanyal et al., (2018). 
Yeast, foliar sprays of bio-stimulant as humic acid and yeast substances have promoted the growth and increases the yield and the quality for a number of plant species .It is increased nutrients uptake, serving as a source of mineral plant nutrients and regulator of their nutrients release (El-Nemr et al., 2012). The bio-stimulators can be applied in the root zone or on the leaves. Abdel Nabi et al., (2014) showed that foliar spraying of cantaloupe plants with yeast extract at $5 \mathrm{~g}$ $\mathrm{L}^{-1}$ significantly surpassed other treatments (without treatments, spraying with EM or Agrispon) and produced the highest values of all the studied parameters of growth and yield. Ahmed et al., (2013) showed that increasing foliar application of active yeast extracts up to $4 \mathrm{~g} \mathrm{~L}^{-1}$ improved the vegetative growth characters of potato plants as expressed as plant length, stems, leaves number/plant, leaf area /plant, fresh and dry weights of the whole plant as well as gave the highest total tuber yield. Shehata et al., (2012) studied the effect of foliar application of yeast rates $\left(1,2,3\right.$ and $\left.4 \mathrm{~g} \mathrm{~L}^{-1}\right)$ on cucumber yield and its component where they showed that active dry yeast increased significantly cucumber yield, number of fruits/plant, average weight of fruit, fruit length and fruit diameter. Also, they mentioned that yeast is an enriched source of phytohormones especially cytokinins, vitamins, enzymes, amino acids and minerals as well as has a stimulatory effect on the cell division and enlargement, protein and nucleic acids synthesis, chlorophyll formation and protective role against different stresses.

Humic acid play a prominent role in various physiological and biochemical processes related to environmental stresses .Humic substances have been shown to stimulate shoot and root growth and nutrients uptake of vegetable crops ,Akinremi et al., ( 2000) . Humic acid have ecological importance, as they intervene in the regulation of a large number of chemical and biological processes that occur in the natural ecosystems, Chen. et al., (2004). One of the strategies to improve forage productivity is the foliar application with humic and fulvic acids as well as amino acids. Foliar spraying with $10 \mathrm{ml} / \mathrm{L} \mathrm{K}$ humate $\left(10 \% \mathrm{~K}_{2} \mathrm{O}\right)$ increased significantly plant height, number of secondary branches /plant, number of heads /plant, dry leaf /stem ratio, number of seeds /head, 1000 seed weight, fresh and dry fodder yields as well as seed yield, followed by foliar spray with $10 \mathrm{ml} / \mathrm{L}$ amino acids mixture and the maximum values of crude protein , $\mathrm{N}, \mathrm{P}$ and $\mathrm{K} \%$ were obtained from treated plants by $10 \mathrm{ml} / \mathrm{L} \mathrm{K}$-humate followed by $10 \mathrm{ml} / \mathrm{L}$ amino acids mixture compared to control Fadia Sultan et al., ( 2016). Asik. et al., (2009) reported that the lowest doses of both soil and foliar application of humic substances increased the nutrient uptake of wheat. Furthermore, El-Hefny (2010) reported significant increases in plant height, number of branches, fresh weight, leaf area /plant, total pods 
yield, N, P, K uptake as well as protein and carbohydrate contents in cowpea seeds with increasing the rate of humic acid application from 1 , 3, 4.5 up to $6 \mathrm{~kg} / \mathrm{fed}$. Ghorbani. et $\boldsymbol{a l}$., (2010) reported that spraying with humic acid showed remarkable effects on vegetative growth of plant and increases photosynthetic activity and increasing leaf area. El-Nemr et al., (2012) found that spraying HA and bio-stimulators through foliar application led to a positive effect on plant growth, fruit-set, yield quantity and quality of cucumber plants. Hafez et al ( 2020 ) studied the effect of the fertigation with four combinations of both humic $(\mathrm{H})$ and Amino acids (A) as (control, $2 \mathrm{~L} \mathrm{H}, 2 \mathrm{~L} \mathrm{~A}$ and $2 \mathrm{~L} \mathrm{H}+2 \mathrm{~L} \mathrm{~A} / \mathrm{fed}$ ) as well as the foliar application of three rates of potassium silicate (KS), i.e. , $(\mathrm{O}, 5$ and $10 \mathrm{~g}) \mathrm{KS} / \mathrm{L}$ on the growth, yield parameters, quality content, uptake of $\mathrm{N}$ and $\mathrm{K}$ of bulb onion plants ,which found that best treatment was observed with the integration treatment of $(\mathrm{H}+\mathrm{A}+10 \mathrm{~g} \mathrm{KS} / \mathrm{l})$ which gave the highest mean values of growth, yield, yield component and quality parameters (TSS \%, Protein \% and carbohydrates \%) during the studied two seasons.

Amino acids are important for stimulation of cell growth. They contain both acid and basic groups and act as buffers, which help to maintain favorable $\mathrm{pH}$ value within the plant cell. Recently, studies have proved that amino acids can directly or indirectly influence the physiological activities in plant growth and development. Also, amino acids are well known as bio stimulants, which have positive effects on plant growth, yield and significantly mitigate the injuries caused by abiotic stresses (Kowalczyk and Zielony, 2008). Liu et al., (2008) revealed that foliar application with the mixture of amino acids to radish plants increased N content of shoots. El-Zohiri and Asfour (2009) on potato found that spraying of amino acids at $0.25 \mathrm{ml} / 1$ significantly increased vegetative growth expressed as plant height and dry weight of plant. Abo Sedera et al., (2010) revealed that spraying strawberry plants with amino acids (peptone) at 0.5 and $1.0 \mathrm{~g} / 1$ significantly increased total nitrogen, phosphorus and potassium in plant foliage as well as total yield, weight of plant TSS, vitamin C and total sugars content of fruits compared with control treatment. Studies have proved that amino acids can directly or indirectly influences the physiological activities in plant growth and development. Many studies reported that, the foliar application of amino acids caused an enhancement in plant growth, fruits yield and its components, on cucumber Karuppaiah et al., (2000), ElShabasi (2005).on garlic, and Awad et al., (2007) on potato. Perez et al., (2015), mentioned that the amino acids activate plant synthesis efficiency and internal immunity in addition improves the qualities of growth and yield. 
Accordingly, this study aims to study the effect of foliar spray with Active dry yeast, humic acid and mixture of Amino acids and their interactions on the growth, productivity and chemical contents of Egyptian clover (c.v. Meskawey) grown in calcareous.

\section{MATERIALS AND METHODS}

The present investigation was carried out during the season of 2018 / 2019 in the Agricultural Experimental Station of the Desert Research Center at Maryout station, $40 \mathrm{~km}$ south -west of Alexandria, Egypt.

The experiment was planned in a split- split plot design with three replicates. The main plots were applying of three levels of Active dry yeast include three rates ( 0,2 and $4 \mathrm{~g} / \mathrm{L}$ ), the subplots included foliar spraying with Humic acid ( $\mathrm{H})$ at rates of $(0,2,4 \mathrm{ml} / \mathrm{L})$, and sub -sub plots were three levels foliar Amino acids mixture at rates of $(0,2$ and $4 \mathrm{ml} /$ L). Foliar spraying of the treatments were added as four times, first after 25 days from planting, which $2^{\text {nd }}$, the $3^{\text {rd. }}$ and the $4^{\text {th }}$ after 10 days of each cutting. Egyptian clover, (Trifolium alexandrinum .L var. Meskaway ) seeds were sown directly ate rate of $60 \mathrm{~kg} /$ fed in the soil at November $20^{\text {th }}$.

All plots were fertilized with the recommended rates of nitrogen (40 $\mathrm{kg} \mathrm{N} / \mathrm{fed})$ as ammonium sulphate and $(200 \mathrm{~kg})$ superphosphate and $\mathrm{K}$ sulphate, (100 kg / fed). Nitrogen , P and K fertilizers were added through twice doses before cultivation and after 25 days from planting, also organic manure (farmyard manure ) at rate of 5 ton /fed was added during soil preparation .The experiment included 27 experimental units , includes 3 Hmic acid treatments , 3 rates of mixture Amino acids and 3 rates of Active dry yeast .The plot area was $\left(10.5 \mathrm{~m}^{2}\right), 3.5 \times 3 \mathrm{~m}$ long and wide ( $1 / 400$ fed) . Seeds before cultivation treated with bio- fertilizer containing the symbiotic N- Fixing bacteria of (Rhizobium leguminosarum) which provided by Soil Microbiology Unit, Soil Fertility and Microbiology Department, Desert Research Center, Cairo Egypt. The soil and irrigation water were analyzed at the laboratories of Desert Research Center, as shown in Tables (1 A, B and 2).

Table 1- A. Some chemical properties of the experimental soil.

\begin{tabular}{|c|c|c|c|c|c|c|c|c|c|c|c|}
\hline $\begin{array}{l}\text { Soil depth } \\
\text { (cm) }\end{array}$ & $\mathrm{pH}$ & $\begin{array}{c}\mathrm{CaCO}_{3} \\
\%\end{array}$ & $\underset{\%}{\mathbf{O M}}$ & $\begin{array}{c}\text { E. C } \\
\text { dSm }^{-1}\end{array}$ & \multicolumn{4}{|c|}{ Soluble Cations ( me/ l) } & \multicolumn{3}{|c|}{ Soluble Anions ( $\mathrm{me} / \mathrm{l}$ ) } \\
\hline \multirow[b]{2}{*}{ 0 - 30 } & \multirow[b]{2}{*}{7.7} & \multirow[b]{2}{*}{28} & \multirow[b]{2}{*}{0.61} & \multirow[b]{2}{*}{4.85} & $\mathrm{Ca}^{++}$ & Mg++ & $\mathrm{Na}^{+}$ & $\mathbf{K}^{+}$ & $\mathrm{HCO}_{3}^{-}$ & SO4$^{=}$ & $\mathrm{Cl}^{-}$ \\
\hline & & & & & 21.57 & 13.62 & 12.5 & 1.1 & 6.23 & 20.98 & 21.24 \\
\hline \multirow{2}{*}{$\begin{array}{c}\text { Available } \\
\text { nutrients } \\
\text { (ppm) }\end{array}$} & \multicolumn{2}{|r|}{$\mathbf{N}$} & \multicolumn{2}{|c|}{$\mathbf{P}$} & \multicolumn{2}{|c|}{$\mathbf{K}$} & \multicolumn{2}{|c|}{ Fe } & Mn & $\mathbf{Z n}$ & $\mathbf{C u}$ \\
\hline & \multicolumn{2}{|r|}{35} & \multicolumn{2}{|c|}{7.83} & \multicolumn{2}{|c|}{13.5} & \multicolumn{2}{|c|}{1.7} & 5.03 & 0.86 & 1.4 \\
\hline
\end{tabular}

pH : Acidity, soil extract $(1: 2.5), \quad \mathrm{E} . \mathrm{C}$ :Electrical conductivity me/ I: mille equivalent per Liter $\mathrm{OM}=$ organic matter 
Table 1- B - Some physical properties of the experimental soil.

\begin{tabular}{|l|c|c|c|c|c|}
\hline \multirow{2}{*}{ Site } & \multicolumn{4}{|l|}{ Particle size distribution } & Texture class \\
\cline { 2 - 5 } & Coarse sand \% & Fine sand\% & Silt \% & Clay \% & \\
\hline Maryout & $\mathbf{5}$ & $\mathbf{4 1 . 8}$ & $\mathbf{3 5 . 0}$ & $\mathbf{1 8 . 2}$ & SCL \\
\hline
\end{tabular}

SCL $=$ Sandy clay loam

Table 2. Chemical analysis of the applied irrigation water.

\begin{tabular}{|c|c|c|c|c|c|c|c|c|c|}
\hline Parameters & pH & $\begin{array}{c}\text { E. C } \\
\text { dSm }^{-1}\end{array}$ & \multicolumn{3}{|c|}{ Soluble Cations ( me/ l) } & \multicolumn{3}{c|}{ Soluble Anions ( me/ l ) } \\
\hline \multirow{2}{*}{ Values } & \multirow{2}{*}{$\mathbf{7 . 5}$} & 2.8 & $\mathrm{Ca}^{++}$ & $\mathbf{M g}++$ & $\mathrm{Na}^{+}$ & $\mathrm{K}^{+}$ & $\mathrm{HCO}_{3}^{-}$ & $\mathrm{SO4}^{-}$ & $\mathrm{Cl}^{-}$ \\
\cline { 4 - 10 } & & $\mathbf{8 . 5 9}$ & $\mathbf{1 0 . 4 3}$ & $\mathbf{8 . 7}$ & $\mathbf{0 . 4 2}$ & $\mathbf{6 . 8 3}$ & $\mathbf{5 . 5 8}$ & $\mathbf{1 5 . 6}$ \\
\hline
\end{tabular}

${ }_{\mathrm{pH}}$ : Acidity, E.C :Electrical conductivity me/ l: mille equivalent per Liter

A liquid commercial product of the used humic acid substance consists of. humic acid $91 \%, 1 \% \mathrm{P}, 1 \% \mathrm{Fe}$ and $1 \% \mathrm{Zn}$. The liquid commercial product of amino acids mixture consists of $(0.56 \%$ leucine, $1.91 \%$ alanine, $1.8 \%$ valine, $0.42 \%$ arginine, $8.1 \%$ glutamic, $0.62 \%$ aspartic, $2.33 \%$ lysine, $0.41 \%$ threonine, $2.36 \%$ phenylalanine, $0.40 \%$ histidin, $2.37 \%$ tyrosine, $2.55 \%$ glycine, $0.42 \%$ isoleucine, $0.29 \%$ serine, $0.46 \%$ proline), $4 \% \mathrm{~N}, 5 \% \mathrm{~K}_{2} \mathrm{O}$ and $1 \% \mathrm{P}_{2} \mathrm{O}_{5}$ were used as a source of amino acids mixture. Yeast extract was prepared from yeast (saccharomyces cerevisiae), dissolved in water followed by adding sugar at a ratio of 1: 1 and kept 24 hours in a warm place for reproduction according to the methods of Marzauk et al., ( 2014 ) chemical analysis of activated yeast is shown in Table ( 3 ).

Egyptian clover Yield:

At harvest time, $1 \mathrm{~m}^{2}$ was taken from the center of each plot of the trial to determine the fresh and dry forage yield kg/ fed. All Egyptian clover plants for each plot plants was harvested to determine: fresh forage yield, dry forage yield and accumulative through the whole season (ton /fed.)

Table (3). Chemical analysis of activated yeast (mg/100 gm dry weight).

\begin{tabular}{|l|l|l|l|l|l|}
\hline \multicolumn{2}{|c|}{ Mineral } & Amino acids & \multicolumn{2}{c|}{ Vitamins } \\
\hline Total N & $\mathbf{7 . 2 3}$ & Arginine & $\mathbf{1 . 9 9}$ & Thiamin & $\mathbf{2 . 7 1}$ \\
\hline P $_{205}$ & $\mathbf{5 1 . 6 8}$ & Histidine & $\mathbf{2 . 6 3}$ & Riboflavin & $\mathbf{4 . 9 6}$ \\
\hline K $_{20}$ & $\mathbf{3 4 . 3 9}$ & Isoleucine & $\mathbf{2 . 3 1}$ & Nicotinic acid & $\mathbf{3 9 . 8 8}$ \\
\hline Mgo & $\mathbf{5 . 7 6}$ & Leucine & $\mathbf{3 . 0 9}$ & Pantothenic acid & $\mathbf{1 9 . 5 6}$ \\
\hline Cao & $\mathbf{3 . 0 5}$ & Lysine & $\mathbf{2 . 9 5}$ & Biotin & $\mathbf{0 . 0 9}$ \\
\hline Sio 2 & $\mathbf{1 . 5 5}$ & Methionine & $\mathbf{0 . 7 2}$ & Pyridoxine & $\mathbf{2 . 9 0}$ \\
\hline So & $\mathbf{0 . 4 9}$ & Phrylalanine & $\mathbf{2 . 0 1}$ & Folic acid & $\mathbf{4 . 3 6}$ \\
\hline Nacl & $\mathbf{0 . 3 0}$ & Threonine & $\mathbf{2 . 0 9}$ & Cabalamine & $\mathbf{1 5 3}$ ug \\
\hline Fe & $\mathbf{0 . 9 2}$ & Tryptophan & $\mathbf{0 . 4 5}$ & Oxidase & $\mathbf{0 . 3 5 0}$ \\
\hline Ba & $\mathbf{1 . 6 7}$ & Valine & $\mathbf{2 . 1 9}$ & Peroxidase & $\mathbf{0 . 2 9 0}$ \\
\hline Co & $\mathbf{6 . 8}$ & Glutamic acid & $\mathbf{2 . 0 0}$ & Catalase & $\mathbf{0 . 0 6 3}$ \\
\hline Pd & $\mathbf{4 . 3 9}$ & Serine & 1.59 & Carbohydrates & $\mathbf{2 3 . 2 0}$ \\
\hline Mn & $\mathbf{8 . 1 . 3}$ & Aspartic acid & 1.33 & & \\
\hline Sn & $\mathbf{2 . 2 4}$ & Praline & 1.53 & & \\
\hline Zn & $\mathbf{3 . 3 6}$ & Tyrosine & 1.49 & & \\
\hline
\end{tabular}




\section{Chemical contents of shoot:}

Nitrogen, phosphorus and potassium were determined in the digested dry matter of Egyptian clover shoots which oven dried at $70^{\circ}$ for 72 hours then fine ground and wet digested according to Peterburgski, (1968) to determined N, P, $\mathrm{K} \%$ according to Chapman and Pratte (1982). Total nitrogen was determined using Microkjeldahl method, Phosphorus content was determined by spectrophotometer, Potassium percentage was determined by using Flame photometer, protein $(\%)$ determination by multiplying N\% of shoot $\times 6.25$.

\section{Statistical Analysis:}

All data were statistically analyzed according to Snedecor and Cochran (1982), where treatments means was compared using L.S.D.test at 0.05 probability level.

\section{Egyptian clover Yield:}

\section{RESULTS AND DISCUSSION}

Foliar spraying of growth promoter substances, i.e., active dry Yeast, humic acid and the mixture of the amino acids had a significant effects on, fresh forage, dry forage and accumulative yields (ton / fed ), as shown in (Table 4 ).

It is noticed that increasing spraying with active dry yeast increased significantly the fresh, dry yields through the taken four cuts and the accumulative yield .The addition of the high rate of yeast $(4 \mathrm{~g} / \mathrm{L})$ had recorded the highest mean values of fresh and dry forage yields ton /fed during the four cuts. The increases of $1^{\text {st }}, 2^{\text {nd }}, 3^{\text {rd }}$ and $4^{\text {th }}$ cuts , reached about $76.2,52.5,52.9$ and $85.8 \%$ for fresh forage while being $85.2,55$, 57.5 and $95.8 \%$ for the dry forage yields /fed , respectively. The highest mean values were 10.633 and 1.886 (ton / fed) with $3^{\text {rd }}$ for fresh and dry forge yields, where, the lowest mean values were $7.816,1.386$ ton /fed for fresh and dry forge yields with the $4^{\text {th }}$ cut .Furthermore, the highest mean values of the accumulative fresh and dry forge yields were 37.87 and 6 .727 (ton /fed), and percentage increase reached about 63.9 and $69.5 \%$ with high spraying rate of yeast compared with control treatment. This increase may due to the role of the addition active dry yeast, Ahmed. et al. (2013) showed that increasing of foliar application of active yeast extracts up to $4 \mathrm{~g}$ $\mathrm{L}^{-1}$ improved the vegetative growth characters of potato. Shehata et al., (2012) studied the effect of foliar application of yeast rates $\left(1,2,3\right.$ or $4 \mathrm{~g} \mathrm{~L}^{-}$ $\left.{ }^{1}\right)$ on cucumber yield and its component and showed that active dry yeast increased significantly cucumber yield, number of fruits/plant, average weight of fruit, fruit length and fruit diameter. Also, Shehata et al., (2012) mentioned that yeast is an enriched source of phytohormones especially cytokinins, vitamins, enzymes, amino acids and minerals as well as has a stimulatory effect on the cell division and enlargement, protein and nucleic acids synthesis, chlorophyll formation and protective role against different stresses . 
Table (4). Effect of the studied treatments on fresh and dry yields of Egyptian clover through four cuts.

\begin{tabular}{|c|c|c|c|c|c|c|c|c|c|c|c|c|}
\hline \multirow{2}{*}{$\begin{array}{c}\text { Yeast } \\
\text { g/l } \\
\text { Y }\end{array}$} & \multirow{2}{*}{$\begin{array}{c}\text { Humic } \\
\text { Acid } \\
\text { ml / l } \\
\text { H }\end{array}$} & \multirow{2}{*}{$\begin{array}{c}\text { Amino } \\
\text { Acid } \\
\text { ml / l } \\
\text { A }\end{array}$} & \multicolumn{4}{|c|}{ Fresh yield ( ton /fed) } & \multirow[b]{2}{*}{$\begin{array}{l}\text { Total } \\
\text { Accu }\end{array}$} & \multicolumn{4}{|c|}{ Dry forage yield ( ton /fed) } & \multirow[b]{2}{*}{$\begin{array}{l}\text { Total } \\
\text { Accu }\end{array}$} \\
\hline & & & $1^{\mathrm{st}}$ & $2^{\text {nd }}$ & $3^{\text {rd }}$ & $4^{\text {th }}$ & & $1^{\text {st }}$ & $2^{\text {nd }}$ & $3^{\text {rd }}$ & $4^{\text {th }}$ & \\
\hline \multirow{9}{*}{0} & \multirow{3}{*}{$\mathbf{0}$} & $\mathbf{0}$ & 5.197 & 6.763 & 6.947 & 4.207 & \begin{tabular}{|l|}
23.114 \\
\end{tabular} & 0.8819 & 1.1787 & 1.2006 & 0.7076 & 3.9688 \\
\hline & & 2 & 5.713 & 7.55 & 7.747 & 5.257 & 26.267 & 0.9877 & 1.3036 & 1.3439 & 0.889 & 4.5242 \\
\hline & & 4 & 6.627 & 8.477 & 8.647 & 5.43 & \begin{tabular}{|l|}
29.181 \\
\end{tabular} & 1.1334 & 1.4514 & 1.484 & 0.9363 & 5.0051 \\
\hline & \multirow{3}{*}{2} & $\mathbf{0}$ & 6.657 & 7.413 & 7.577 & 5.39 & 27.037 & 1.1749 & 1.3062 & 1.3415 & 0.9406 & 4.7632 \\
\hline & & 2 & 6.813 & 8.883 & 9.327 & 5.523 & 30.546 & 1.2028 & 1.6003 & 1.6498 & 0.9619 & 5.4148 \\
\hline & & 4 & 8.07 & 8.963 & 9.607 & 6.53 & 33.17 & 1.4305 & 1.5828 & 1.6956 & 1.1443 & 5.8532 \\
\hline & \multirow{3}{*}{4} & $\mathbf{0}$ & 6.993 & 8.047 & 8.363 & 5.683 & \begin{tabular}{|l|}
29.086 \\
\end{tabular} & 1.2599 & 1.4612 & 1.5013 & 1.0122 & 5.2346 \\
\hline & & 2 & 7.523 & 9.98 & 10.39 & 6.027 & 33.92 & 1.3573 & 1.8048 & 1.758 & 1.0821 & 6.0022 \\
\hline & & 4 & 8.05 & 10.71 & 10.93 & 6.427 & \begin{tabular}{|l|}
36.117 \\
\end{tabular} & 1.4516 & 1.9262 & 1.975 & 1.1518 & 6.5046 \\
\hline \multirow{9}{*}{2} & \multirow{3}{*}{$\mathbf{0}$} & $\mathbf{0}$ & 6.08 & 7.043 & 7.18 & 5.13 & \begin{tabular}{|l|}
25.433 \\
\end{tabular} & 1.0314 & 1.2178 & 1.2348 & 0.8872 & 4.3712 \\
\hline & & 2 & 6.63 & 7.857 & 8.144 & 6.22 & \begin{tabular}{|l|}
28.851 \\
\end{tabular} & 1.1459 & 1.3633 & 1.404 & 1.0586 & 4.9718 \\
\hline & & 4 & 7.787 & 8.893 & 9.29 & 6.49 & 32.46 & 1.3371 & 1.5424 & 1.5847 & 1.0936 & 5.5578 \\
\hline & \multirow{3}{*}{2} & $\mathbf{0}$ & 8.523 & 9.427 & 9.647 & 7.387 & \begin{tabular}{|l|}
34.984 \\
\end{tabular} & 1.5021 & 1.6707 & 1.7135 & 1.3007 & 6.187 \\
\hline & & 2 & 8.947 & 10.53 & 10.8103 & 7.72 & \begin{tabular}{|l|}
38.0073 \\
\end{tabular} & 1.5931 & 1.8671 & 1.9096 & 1.3603 & 6.7301 \\
\hline & & 4 & 9.293 & 10.923 & 11.243 & 8.503 & \begin{tabular}{|l|}
39.962 \\
\end{tabular} & 1.6356 & 1.934 & 1.9898 & 1.4961 & 7.0555 \\
\hline & \multirow{3}{*}{4} & $\mathbf{0}$ & 9.667 & 10.677 & 10.927 & 8.233 & \begin{tabular}{|l|}
39.504 \\
\end{tabular} & 1.7456 & 1.9257 & 1.9095 & 1.5022 & 7.083 \\
\hline & & 2 & 10.367 & 11.793 & 12.1 & 9.363 & \begin{tabular}{|l|}
43.623 \\
\end{tabular} & 1.8748 & 2.1381 & 2.2059 & 1.6855 & 7.9043 \\
\hline & & 4 & 10.84 & 12.217 & 12.473 & 9.367 & \begin{tabular}{|l|}
44.897 \\
\end{tabular} & 1.9507 & 2.2184 & 2.2486 & 1.6913 & 8.109 \\
\hline \multirow{9}{*}{4} & \multirow{3}{*}{ 0 } & $\mathbf{0}$ & 6.563 & 7.227 & 7.403 & 5.713 & 26.906 & 1.127 & 1.2305 & 1.2723 & 0.9834 & 4.6132 \\
\hline & & 2 & 7.89 & 8.223 & 8.45 & 6.457 & 31.02 & 1.346 & 1.4272 & 1.4614 & 1.0956 & 5.3302 \\
\hline & & 4 & 7.81 & 9.077 & 9.517 & 6.553 & 32.957 & 1.3525 & 1.5676 & 1.6252 & 1.1277 & 5.673 \\
\hline & \multirow{3}{*}{2} & $\mathbf{0}$ & 8.98 & 9.877 & 9.977 & 7.633 & \begin{tabular}{|l|}
36.467 \\
\end{tabular} & 1.5887 & 1.7523 & 1.7711 & 1.3491 & 6.4612 \\
\hline & & 2 & 9.917 & 11.057 & 11.313 & 8.373 & 40.66 & 1.7591 & 1.9664 & 2.0019 & 1.4747 & 7.2021 \\
\hline & & 4 & 10.227 & 11.287 & 11.573 & 8.42 & 41.507 & 1.8079 & 2.0138 & 2.0451 & 1.4973 & 7.3641 \\
\hline & \multirow{3}{*}{4} & $\mathbf{0}$ & 9.68 & 10.237 & 11.007 & 8.427 & 39.351 & 1.7699 & 1.8734 & 1.9433 & 1.5387 & 7.1253 \\
\hline & & 2 & 10.433 & 12.36 & 13.09 & 9.2 & 45.083 & 1.9079 & 2.2645 & 2.3996 & 1.6795 & 8.2515 \\
\hline & & 4 & 10.953 & 12.997 & 13.363 & 9.567 & 46.88 & 1.9841 & 2.3627 & 2.4504 & 1.7265 & 8.5237 \\
\hline \multicolumn{13}{|c|}{ LSD at 0.05} \\
\hline \multicolumn{3}{|c|}{$\mathbf{Y}$} & 0.043 & 0.0048 & 0.072 & 0.039 & 0.12 & 1.3 & 1.4 & 102.4 & 1.5 & 0.11 \\
\hline \multicolumn{3}{|c|}{$\mathbf{H}$} & 0.199 & 0.199 & 0.281 & 0.222 & 0.87 & 20.5 & 20.4 & 129.2 & 17.7 & 0.12 \\
\hline \multicolumn{3}{|c|}{$\mathbf{A}$} & 0.050 & 0.056 & 0.196 & 0.059 & 0.23 & 4.3 & 4.5 & 109.6 & 3.9 & 0.11 \\
\hline \multicolumn{3}{|c|}{$\mathbf{Y} \times \mathbf{H}$} & 0.074 & 0.083 & 0.124 & 0.066 & 0.21 & 2.3 & 2.4 & 177.4 & 2.5 & 0.18 \\
\hline & $\mathbf{Y} \times \mathbf{A}$ & & 0.074 & 0.083 & 0.124 & 0.066 & 0.21 & 2.3 & 2.4 & 177.4 & 2.5 & 0.18 \\
\hline & $\mathbf{H} \times \mathbf{A}$ & & 0.086 & 0.097 & 0.339 & 0.102 & 0.40 & 7.47 & 7.8 & 189.9 & 6.8 & 0.19 \\
\hline & $\mathbf{Y} \times \mathbf{H} \times$ & & 0.128 & 0.143 & 0.215 & 0.115 & 0.36 & 4.0 & 4.1 & 307.3 & 4.4 & 0.32 \\
\hline
\end{tabular}

Also, data indicating that increasing spraying rate of humic acid increased significantly the fresh and dry forge yields through the taken four cuts and the accumulative yields, the increases reached about 76.2 , $62.7,64.2$ and $90 \%$ for the fresh forage yield .The corresponding increase of the dry forage yield reached $93.2,61.9,60.8$, and $104 \%$ with application the high rate humic acid $(4 \mathrm{ml} / \mathrm{L})$ in $1^{\text {st }}, 2^{\text {nd }}, 3^{\text {rd }}$ and the $4 \mathrm{t}^{\mathrm{h}}$ cuts, respectively. Which, the highest mean values were 11.41 and 1.932 (ton / fed) with $3^{\text {rd }}$ cut for fresh and dry forge yields. 
Furthermore, the highest mean values of the accumulative fresh and dry forge yields were 39.83 and 6.84 (ton /fed), and the highest percentage increase were 72.3 and $72.3 \%$ with spraying the highest rate of humic acid ( $4 \mathrm{ml} / 1$ ) compared with control treatment. This increase may due to the role of humic acid which play a prominent role in various physiological and biochemical processes related to environmental stresses. Humic acid have ecological importance, as they intervene in the regulation of a large number of chemical and biological processes that occur in the natural ecosystems Chen et al., (2004). Ghorbani et al., (2010) reported that foliar spraying with humic acid has remarkable effects on vegetative growth of plant and increases photosynthetic activity and leaf area. El-Nemr et al., (2012) found that spraying HA and bio-stimulators through foliar application led to a positive effect on plant growth.

Moreover, it is obviously showed that increasing application of the mixture amino acids increased significantly the fresh and dry forge yields through the taken four cuts and the accumulative yields. The increases reached about $73.1,53.7,52.9$ and $77.7 \%$ for fresh yield,while being $78.4,55.9,80.8$ and $85.9 \%$ for the dry forage yields with spraying the highest rat amino acid mixture $(4 \mathrm{ml} / \mathrm{L})$ for $1^{\text {st }}, 2^{\text {nd }}, 3^{\text {rd }}$ and the $4 \mathrm{t}^{\mathrm{h}}$ cuts, respectively. The highest mean values were 10.63 and1.89 ton / fed were obtained at the $3^{\text {rd }}$ cut for fresh and of dry forge yields, while, the lowest mean values were $6.42,1.14$ (ton /fed) for fresh and dry forge yields were obtained with the $4^{\text {th }}$ cut .Generally, the highest mean values of the accumulative fresh and dry forge yields were 37.46 and 6.63 (ton /fed), and the percentage increase reached by about_62 and $67 \%$ with spraying the high level mixture amino acid (4 ml / 1 ) compared with control treatment. This increase of fresh and dry yields (Egyptian clover) can directly or indirectly influences the physiological activities in plant growth and development. Many studies reported that, the foliar application of amino acids caused an enhancement in plant growth, fruits yield and its components, on cucumber Karuppaiah et al., (2000), ElShabasi (2005).on garlic and Awad et al., (2007) on potato. Perez et al. (2015), mentioned that the amino acids actives plant synthesis efficiency and internal immunity in addition to improves the qualities of growth and yield.

For the double interaction $(\mathrm{Y} \times \mathrm{H}),(\mathrm{Y} \times \mathrm{A})$ and $(\mathrm{H} \times \mathrm{A})$ they increased significantly the fresh and the dry yields of Egyptian clover through the studied four cuts and the accumulative yield. The spraying with the higher rates of both humic and the mixture of amino acids $(4 \mathrm{ml} /$ 
L) with high rate of yeast ( $4 \mathrm{~g} / \mathrm{L})$ indicated the higher significantly of fresh, dry and the accumulative yields represent. Where the highest increase of the accumulative fresh and dry yields were with interaction $(\mathrm{Y} \times \mathrm{H})$.

Respective the triple interaction among the studied treatments $(\mathrm{Y} \times \mathrm{H} \times \mathrm{A})$ data indicated significant positive effect on the fresh yields for the four cuts and the accumulative of them. Where spraying plants with the higher rates $4 \mathrm{ml} / \mathrm{L}$ of both humic \& amino acids and $4 \mathrm{~g} / \mathrm{L}$ of dry yeast ) showed the higher fresh, dry yields for each cut and the accumulative yield. The increases reached about 114, 96.5, 92.4 and 127 $\%$ for the four fresh cuts and 125, 100, 104 and 143.7\% for the four dry cuts yields compared to control treatment. Where the increases of accumulative yield reached about 102.9 and $114 \%$ for fresh and dry yields. As mentioned before the higher yields were found in the $2^{\text {nd }}$ cut and the $3^{\text {rd }}$ cut, while the lowest was found in the $4^{\text {th }}$ cut.

Effect of the applied treatments on $\mathrm{N}$ and protein content:

Data in Table (5) and figs ( 1 and 2) indicated that increasing rate of yeast application increased $\mathrm{N}$ concentration, protein percentage and significantly $\mathrm{N}$ uptake. The highest percentage increases reached about $99.8,69.7,73.8$ and $121.7 \%$ for $\mathrm{N}$ uptake \& 8.2, 9.39, 10.6 and $9.8 \%$ , for protein due to the studied four cuts and $87.5 \%$ for the accumulative $\mathrm{N}$ uptake at all season, respectively with higher application rate of yeast compared to control .

Regarding the foliar application with humic acid, data showed that increasing rate of humic acid application increased $\mathrm{N}$ concentration, protein percentage and significantly $\mathrm{N}$ uptake. The increases of $\mathrm{N}$ uptake reached about 108, 84.6, 76.4 and $130 \% \& 3.5,6.9,9.5$ and $11.9 \%$ for protein content by studied four cuts, respectively while being $99 \%$ for the accumulative $\mathrm{N}$ uptake at the whole season, respectively with application the high rate of humic acid $(4 \mathrm{ml} / \mathrm{L})$ compared with control treatment.

It is obviously, increasing application rate of amino acid increased $\mathrm{N}$ concentration, protein and significantly $\mathrm{N}$ uptake for the studied four cuts and the accumulative. The increases of $\mathrm{N}$ uptake reached about 90.4, $70,73.4$ and $108.5 \%$ while being $7.5,8.5,9.5$ and $11.8 \%$ for protein content through the studied four cuts, respectively and $83 \%$ for the accumulative $\mathrm{N}$ uptake.

Respecting the double interactions $(\mathrm{Y} \times \mathrm{H}),(\mathrm{Y} \times \mathrm{A})$ and $(\mathrm{H} \times \mathrm{A})$ they increased of both $\mathrm{N}$ concentration \& protein content and significantly the 
$\mathrm{N}$ uptake through studied four cuts where $(\mathrm{y} \times \mathrm{H})$ showed the highest values of the studied parameters.

For the effect of triple interaction among the studied treatments $(\mathrm{Y} \times \mathrm{H} \times \mathrm{A})$ data indicated increases of both $\mathrm{N}$ concentration \& protein content and significantly the $\mathrm{N}$ uptake through the studied four cuts. Foliar application by the higher rate of yeast ( $4 \mathrm{~g} / \mathrm{L})$, humic and amino acids ( $4 \mathrm{ml} / \mathrm{L}$ ) indicated increases reached about $159.6,136.6,141$ and $189 \%$ for $\mathrm{N}$ uptake \& $15.4,18,18.2$ and $18.6 \%$ for protein content through the studied four cuts, respectively awhile being $152 \%$ for the accumulative $\mathrm{N}$ uptake at whole cuts of the season.

Table (5). Effect of the studied treatments on $N$ uptake $(\mathrm{kg} / \mathrm{fed})$ and protein content (\%) of dry s Egyptian clovers hoot through the four cuts.

\begin{tabular}{|c|c|c|c|c|c|c|c|c|c|c|c|}
\hline \multirow{2}{*}{$\begin{array}{c}\text { Yeast } \\
\text { g/l } \\
\text { Y }\end{array}$} & \multirow{2}{*}{$\begin{array}{c}\text { Humic } \\
\text { Acid } \\
\text { ml / l } \\
\text { H }\end{array}$} & \multirow{2}{*}{$\begin{array}{c}\text { Amino } \\
\text { Acid } \\
\text { ml / l } \\
\text { A }\end{array}$} & \multicolumn{4}{|c|}{ N uptake ( $\mathrm{kg} /$ fed) } & \multirow[b]{2}{*}{$\begin{array}{l}\text { Total } \\
\text { Accu }\end{array}$} & \multicolumn{4}{|c|}{ Protein (\%) } \\
\hline & & & $1^{\text {st }}$ & $2^{\text {nd }}$ & $3^{\text {rd }}$ & $4^{\text {th }}$ & & $1^{\text {st }}$ & $2^{\text {nd }}$ & $3^{\text {rd }}$ & $4^{\text {th }}$ \\
\hline \multirow[b]{9}{*}{ 0 } & \multirow[b]{3}{*}{$\mathbf{0}$} & $\mathbf{0}$ & 13.4 & 18.07 & 18.49 & 10.33 & 60.29 & 9.50 & 9.58 & 9.63 & 9.13 \\
\hline & & 2 & 15.08 & 20.08 & 20.79 & 13.09 & 69.04 & 9.54 & 9.63 & 9.67 & 9.21 \\
\hline & & 4 & 17.45 & 22.54 & 23.34 & 13.92 & 77.25 & 9.63 & 9.71 & 9.83 & 9.29 \\
\hline & \multirow[b]{3}{*}{2} & $\mathbf{0}$ & 18.01 & 20.29 & 20.93 & 14.55 & 73.78 & 9.58 & 9.71 & 9.75 & 9.67 \\
\hline & & 2 & 18.68 & 25.17 & 26.4 & 15.07 & 85.32 & 9.71 & 9.83 & 10.00 & 9.79 \\
\hline & & 4 & 22.32 & 25.32 & 27.35 & 18.16 & 93.15 & 9.75 & 10.00 & 10.08 & 9.92 \\
\hline & \multirow[b]{3}{*}{4} & $\mathbf{0}$ & 19.74 & 22.98 & 23.72 & 15.86 & 82.3 & 9.79 & 9.83 & 9.88 & 9.79 \\
\hline & & 2 & 21.54 & 29 & 28.71 & 17.31 & 96.56 & 9.92 & 10.04 & 10.21 & 10.00 \\
\hline & & 4 & 23.33 & 31.34 & 32.65 & 18.43 & 105.75 & 10.04 & 10.17 & 10.33 & 10.00 \\
\hline \multirow[b]{9}{*}{2} & \multirow[b]{3}{*}{ 0 } & 0 & 16.09 & 19.08 & 19.42 & 13.78 & 68.37 & 9.75 & 9.79 & 9.83 & 9.71 \\
\hline & & 2 & 18.03 & 21.54 & 22.46 & 16.73 & 78.76 & 9.83 & 9.88 & 10.00 & 9.88 \\
\hline & & 4 & 21.39 & 24.88 & 25.67 & 17.64 & 89.58 & 10.00 & 10.08 & 10.13 & 10.08 \\
\hline & \multirow[b]{3}{*}{2} & $\mathbf{0}$ & 23.73 & 26.51 & 27.3 & 20.38 & 97.92 & 9.88 & 9.92 & 9.96 & 9.79 \\
\hline & & 2 & 25.6 & 30.49 & 31.83 & 21.76 & 109.68 & 10.04 & 10.21 & 10.42 & 10.00 \\
\hline & & 4 & 26.94 & 32.49 & 33.83 & 24.24 & 117.5 & 10.29 & 10.50 & 10.63 & 10.13 \\
\hline & \multirow[b]{3}{*}{4} & 0 & 27.93 & 31.06 & 31.07 & 24.23 & 114.29 & 10.00 & 10.08 & 10.17 & 10.08 \\
\hline & & 2 & 30.75 & 35.77 & 37.65 & 27.52 & 131.69 & 10.25 & 10.46 & 10.67 & 10.21 \\
\hline & & 4 & 32.52 & 38.16 & 39.42 & 28.41 & 138.51 & 10.42 & 10.75 & 10.96 & 10.50 \\
\hline \multirow{9}{*}{4} & \multirow[b]{3}{*}{ 0 } & 0 & 17.81 & 19.6 & 20.52 & 15.47 & 73.4 & 9.88 & 9.96 & 10.08 & 9.83 \\
\hline & & 2 & 21.54 & 23.41 & 24.36 & 17.67 & 86.98 & 10.00 & 10.25 & 10.42 & 10.08 \\
\hline & & 4 & 22.09 & 26.13 & 27.74 & 18.8 & 94.76 & 10.21 & 10.42 & 10.67 & 10.42 \\
\hline & \multirow[b]{3}{*}{2} & 0 & 25.42 & 28.26 & 28.82 & 21.76 & 104.26 & 10.00 & 10.08 & 10.17 & 10.08 \\
\hline & & 2 & 28.85 & 33.04 & 34.69 & 24.48 & 121.06 & 10.25 & 10.50 & 10.83 & 10.38 \\
\hline & & 4 & 30.25 & 34.5 & 35.85 & 25.75 & 126.35 & 10.46 & 10.71 & 10.96 & 10.75 \\
\hline & \multirow[b]{3}{*}{4} & 0 & 28.67 & 30.72 & 32.39 & 25.03 & 116.81 & 10.13 & 10.25 & 10.42 & 10.17 \\
\hline & & 2 & 32.57 & 39.4 & 42.06 & 28 & 142.03 & 10.67 & 10.88 & 10.96 & 10.42 \\
\hline & & 4 & 34.78 & 42.76 & 44.6 & 29.92 & 152.06 & 10.96 & 11.31 & 11.38 & 10.83 \\
\hline \multicolumn{12}{|c|}{\begin{tabular}{|l} 
LSD at 0.05 \\
\end{tabular}} \\
\hline \multicolumn{3}{|c|}{$\mathbf{Y}$} & 0.05 & 0.08 & 0.42 & 0.04 & & & & & \\
\hline \multicolumn{3}{|c|}{$\mathbf{H}$} & 0.59 & 0.60 & 0.98 & 0.53 & & & & & \\
\hline \multicolumn{3}{|c|}{$\mathbf{A}$} & 0.16 & 0.19 & 0.56 & 0.14 & & & & & \\
\hline \multicolumn{3}{|c|}{$\mathbf{Y} \times \mathbf{H}$} & 0.08 & 0.09 & 0.73 & 0.07 & & & & & \\
\hline \multicolumn{3}{|c|}{$\mathbf{Y} \times \mathbf{A}$} & 0.08 & 0.09 & 0.73 & 0.07 & & & & & \\
\hline \multicolumn{3}{|c|}{$\mathbf{H} \times \mathbf{A}$} & 0.27 & 0.28 & 0.96 & 0.24 & & & & & \\
\hline & $\times \mathbf{H} \times A$ & & 0.14 & 0.15 & 0.22 & 0.12 & & & & & \\
\hline
\end{tabular}




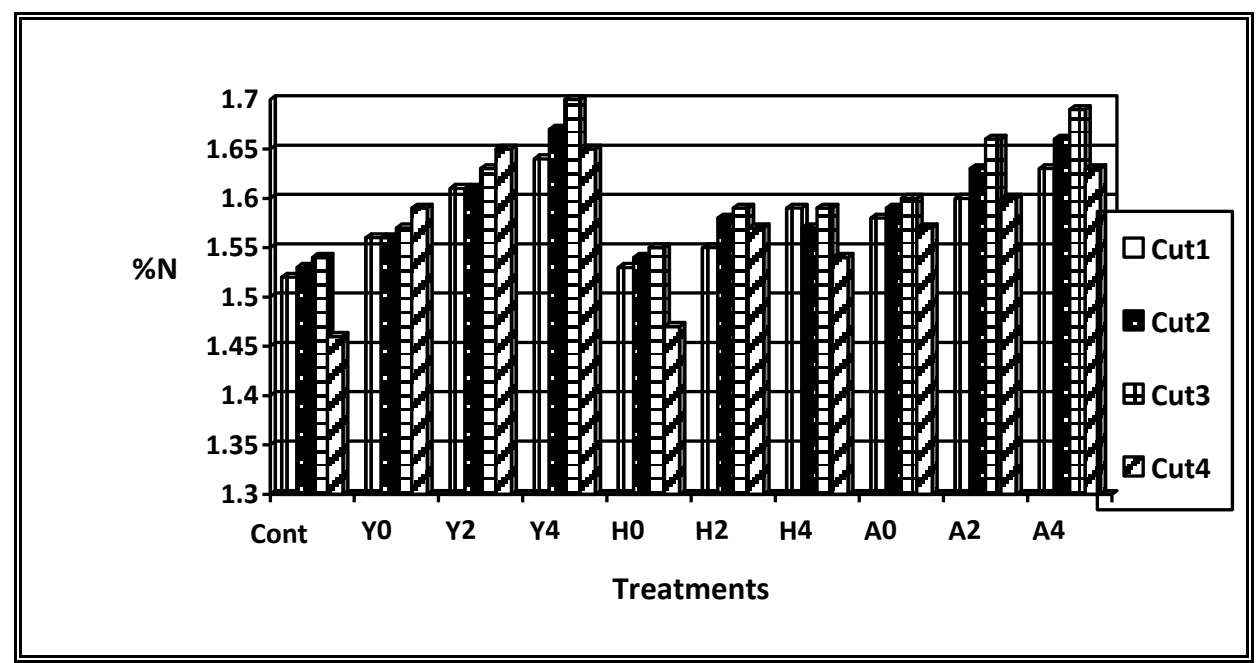

Fig (1). Effect of the studied treatments on N\% of Egyptian clover through four cuts.

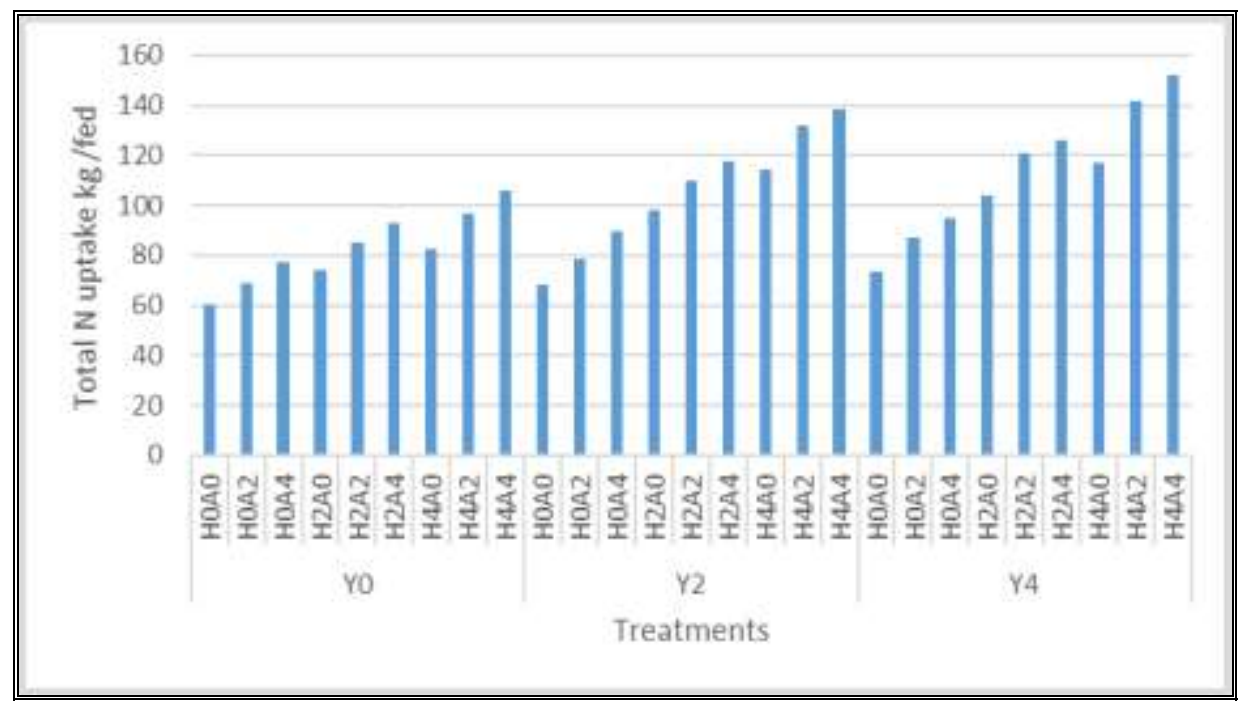

Fig (2) .Effect of the studied treatments on the accumulative $\mathrm{N}$ uptake at whole season (kg/fed.).

\section{Effect of the applied treatments on $P$ content:}

Data in Table (6) and figs (3 and 4) indicated that increasing rate of yeast application increased $\mathrm{P}$ concentration and significantly $\mathrm{P}$ uptake. The highest percentage increases reached about 151, 121, 130 and $166 \%$ for P uptake by studied four cuts and 144\% for the accumulative P uptake at whole season, respectively with higher application rate of yeast compared with control treatment. 
Regarding the foliar application with humic acid, data showed that increasing rate of humic acid application increased $\mathrm{P}$ concentration, and significantly $\mathrm{N}$ uptake. The increases of $\mathrm{P}$ uptake reached about 162, 140, 143 and $177 \%$ due to the studied four cuts, respectively and $160 \%$ for accumulative $\mathrm{P}$ uptake at whole season, respectively with higher application rate of humic acid $(4 \mathrm{ml} / \mathrm{L})$ compared with control treatment.

Increasing application rate of amino acid increased $\mathrm{P}$ concentration and significantly $\mathrm{P}$ uptake for the studied four cuts and the accumulative. The increases of $\mathrm{P}$ uptake reached about 133, 132, 121 and 145\% through the studied four cuts, respectively and $132 \%$ for the accumulative $P$ uptake.

Respecting the double interaction $(\mathrm{Y} \times \mathrm{H}),(\mathrm{Y} \times \mathrm{A})$ and $(\mathrm{H} \times \mathrm{A})$ they increased of both $\mathrm{P}$ concentration and significantly the $\mathrm{P}$ uptake through studied four cuts. Where the interaction between $(\mathrm{y} \times \mathrm{H})$ showed the higher increase of both $\mathrm{P}$ concentration and uptake.

For the effect of triple interaction among the studied treatments $(\mathrm{Y} \times \mathrm{H} \times \mathrm{A})$ data indicated that increases of both $\mathrm{P}$ concentration and significantly the $\mathrm{P}$ uptake through the studied four cuts. Foliar application by the higher rate of yeast ( $4 \mathrm{~g} / \mathrm{L})$, humic and amino acids ( $4 \mathrm{ml} / \mathrm{L}$ ) indicated increases reached to about 271, 240,264 and 298\% for P uptake through the studied four cuts, respectively and $264 \%$ for P accumulative uptake at whole season .

\section{Effect of the applied treatments on $K$ content:}

Data in Table (6) and figs (5 and 6) indicated that increasing rate application of yeast increased $\mathrm{K}$ concentration and significantly $\mathrm{K}$ uptake. The highest percentage increases reached about 189,147, 85 and $131 \%$ for $\mathrm{K}$ uptake by studied four cuts and $113 \%$ for the accumulative K uptake at whole season, respectively with application the higher rate of yeast ( $4 \mathrm{~g} / \mathrm{L}$ ) compared to control.

It is noticed that, increasing rate of humic acid application increased $\mathrm{K}$ concentration, and significantly $\mathrm{K}$ uptake. The increases of $\mathrm{K}$ uptake reached by about 162.6, 140.6, 142.7 and $177 \%$ due to the studied four cuts, respectively and $160 \%$ for the accumulative $\mathrm{P}$ uptake at whole season, respectively with higher application rate of humic acid (4 $\mathrm{ml} / \mathrm{L}$ ) compared with control treatment.

Increasing application rate of amino acid increased $\mathrm{K}$ concentration and significantly $\mathrm{K}$ uptake for the studied four cuts and the accumulative $\mathrm{K}$ uptake. The increases of $\mathrm{K}$ uptake reached to about 133, 131.7, 121 and $145 \%$ through the studied four cuts, respectively and $132 \%$ for the accumulative $\mathrm{K}$ uptake.

Respecting the double interaction $(\mathrm{Y} \times \mathrm{H}),(\mathrm{Y} \times \mathrm{A})$ and $(\mathrm{H} \times \mathrm{A})$ they increased of both $\mathrm{K}$ concentration and significantly the $\mathrm{K}$ uptake through 
studied four cuts. The interaction $(\mathrm{Y} \times \mathrm{H})$ showed the highest values of $\mathrm{K}$ concentration and uptake.

For the effect of the triple interaction among the studied treatments $(\mathrm{Y} \times \mathrm{H} \times \mathrm{A})$, data indicated increases of both $\mathrm{K}$ concentration and significantly the $\mathrm{K}$ uptake through studied four cuts. Application the higher rate of yeast ( $4 \mathrm{~g} / \mathrm{L})$, humic and amino acids $(4 \mathrm{ml} / \mathrm{L}$ ) indicated increases reached to about $271,240,264$ and $298 \%$ for k uptake through the studied four cuts, respectively and $264 \%$ for the accumulative K uptake at whole season .

Table (6). Effect of the studied treatments on $P$ and $K$ uptake (kg /fed) of dry shoot Egyptian clover through four cuts.

\begin{tabular}{|c|c|c|c|c|c|c|c|c|c|c|c|c|}
\hline \multirow{2}{*}{$\begin{array}{c}\text { Yeast } \\
\mathrm{g} / \mathrm{l} \\
\mathrm{Y}\end{array}$} & \multirow{2}{*}{$\begin{array}{c}\text { Humic } \\
\text { Acid } \\
\text { ml / l } \\
\text { H }\end{array}$} & \multirow{2}{*}{$\begin{array}{c}\text { Amino } \\
\text { Acid } \\
\text { ml / l } \\
\text { A }\end{array}$} & \multicolumn{4}{|c|}{ P uptake ( kg /fed) } & \multirow[b]{2}{*}{$\begin{array}{l}\text { Total } \\
\text { Accu }\end{array}$} & \multicolumn{4}{|c|}{ K uptake (kg /fed) } & \multirow[b]{2}{*}{$\begin{array}{l}\text { Total } \\
\text { Accu }\end{array}$} \\
\hline & & & $\mathbf{1}^{\mathrm{st}}$ & $2^{\text {nd }}$ & $3^{\text {rd }}$ & $4^{\text {th }}$ & & $1^{\text {st }}$ & $2^{\text {nd }}$ & $3^{\text {rd }}$ & $4^{\text {th }}$ & \\
\hline \multirow{9}{*}{$\mathbf{0}$} & \multirow{3}{*}{$\mathbf{0}$} & $\mathbf{0}$ & 2.03 & 2.71 & 2.76 & 1.56 & 9.06 & 2.85 & 3.84 & 5.32 & 3.18 & 15.19 \\
\hline & & 2 & 2.27 & 3.00 & 3.09 & 1.87 & 10.23 & 3.29 & 4.41 & 6.32 & 4.24 & 18.26 \\
\hline & & 4 & 2.61 & 3.34 & 3.56 & 2.06 & 11.57 & 3.83 & 5.02 & 7.08 & 4.56 & 20.49 \\
\hline & \multirow{3}{*}{2} & $\mathbf{0}$ & 2.82 & 3.13 & 3.22 & 2.16 & 11.33 & 3.91 & 4.41 & 6.26 & 4.58 & 19.16 \\
\hline & & 2 & 3.13 & 4.16 & 4.45 & 2.4 & 14.14 & 4.16 & 5.65 & 7.97 & 4.81 & 22.59 \\
\hline & & 4 & 3.86 & 4.43 & 4.75 & 3.09 & 16.13 & 5.05 & 5.67 & 8.36 & 6.03 & 25.11 \\
\hline & \multirow{3}{*}{4} & $\mathbf{0}$ & 3.28 & 3.8 & 4.05 & 2.53 & 13.66 & 4.3 & 5.06 & 7.21 & 5.16 & 21.73 \\
\hline & & 2 & 3.8 & 5.05 & 5.27 & 2.92 & 17.04 & 4.89 & 6.64 & 8.79 & 5.92 & 26.24 \\
\hline & & 4 & 4.06 & 5.59 & 5.93 & 3.11 & 18.69 & 5.41 & 7.28 & 10.21 & 6.65 & 29.55 \\
\hline \multirow{9}{*}{2} & \multirow{3}{*}{ 0 } & $\mathbf{0}$ & 2.48 & 3.04 & 3.09 & 2.04 & 10.65 & 4.57 & 5.44 & 5.59 & 4.05 & 19.65 \\
\hline & & 2 & 2.86 & 3.54 & 3.79 & 2.65 & 12.84 & 5.35 & 6.5 & 6.88 & 5.11 & 23.84 \\
\hline & & 4 & 3.48 & 4.16 & 4.28 & 2.73 & 14.65 & 6.42 & 7.56 & 7.92 & 5.5 & 27.4 \\
\hline & \multirow{3}{*}{2} & $\mathbf{0}$ & 3.91 & 4.51 & 4.63 & 3.25 & 16.3 & 6.86 & 7.8 & 8.1 & 6.76 & 29.52 \\
\hline & & 2 & 4.78 & 5.97 & 6.3 & 3.94 & 20.99 & 7.85 & 9.39 & 9.87 & 6.94 & 34.05 \\
\hline & & 4 & 5.23 & 6.38 & 6.57 & 4.64 & 22.82 & 8.34 & 10.06 & 10.49 & 8.03 & 36.92 \\
\hline & \multirow{3}{*}{4} & 0 & 4.71 & 5.39 & 5.54 & 3.61 & 19.25 & 8.2 & 9.19 & 9.22 & 7.81 & 34.42 \\
\hline & & 2 & 6.19 & 7.7 & 8.38 & 5.39 & 27.66 & 9.75 & 11.27 & 11.85 & 9.39 & 42.26 \\
\hline & & 4 & 6.83 & 8.43 & 8.77 & 5.58 & 29.61 & 10.59 & 12.2 & 12.43 & 9.81 & 45.03 \\
\hline \multirow{9}{*}{4} & \multirow{3}{*}{ 0 } & 0 & 2.93 & 3.32 & 3.44 & 2.46 & 12.15 & 5.07 & 5.62 & 5.94 & 4.59 & 21.22 \\
\hline & & 2 & 3.5 & 3.85 & 4.09 & 2.74 & 14.18 & $\begin{array}{l}6.42 \\
\end{array}$ & 6.89 & 7.31 & 5.55 & 26.17 \\
\hline & & 4 & 3.79 & 4.39 & 4.71 & 2.93 & 15.82 & 6.59 & 7.89 & 8.29 & 5.79 & 28.56 \\
\hline & \multirow{3}{*}{2} & $\mathbf{0}$ & 4.29 & 5.43 & 5.67 & 3.64 & 19.03 & 7.74 & 9.11 & 8.86 & 7.24 & 32.95 \\
\hline & & 2 & 6.16 & $\begin{array}{l}6.88 \\
\end{array}$ & 7.21 & 4.87 & 25.12 & 8.8 & 10.03 & 10.35 & 7.96 & 37.14 \\
\hline & & 4 & 6.33 & 7.65 & 7.77 & 5.09 & 26.84 & 9.53 & 10.81 & 11.1 & 8.19 & 39.63 \\
\hline & \multirow{3}{*}{4} & $\overline{0}$ & 5.49 & 5.99 & 6.22 & 4.46 & 22.16 & 9.03 & 9.74 & 10.3 & 8.31 & 37.38 \\
\hline & & 2 & 6.87 & 8.61 & 9.6 & 5.88 & 30.96 & 10.44 & 12.61 & 13.44 & 9.52 & 46.01 \\
\hline & & 4 & 7.54 & 9.21 & 10.05 & 6.22 & 33.02 & 11.45 & 13.7 & 14.21 & 9.79 & 49.15 \\
\hline \multicolumn{3}{|c|}{ LSD at 0.05} & & & & & & & & & & \\
\hline \multicolumn{3}{|c|}{$\mathbf{Y}$} & 0.01 & 0.02 & 0.08 & 0.03 & & 0.02 & 0.03 & 0.12 & 0.01 & \\
\hline \multicolumn{3}{|c|}{$\mathbf{H}$} & 0.11 & 0.12 & 0.18 & 0.09 & & 0.17 & 0.18 & 0.30 & 0.17 & \\
\hline \multicolumn{3}{|c|}{$\mathbf{A}$} & 0.03 & 0.35 & 0.11 & 0.04 & & 0.05 & 0.06 & 0.17 & 0.04 & \\
\hline \multicolumn{3}{|c|}{$\mathbf{Y} \times \mathbf{H}$} & 0.02 & 0.06 & 0.14 & 0.02 & & 0.08 & 0.03 & 0.22 & 0.02 & \\
\hline & $\mathbf{Y} \times \mathbf{A}$ & & 002 & 0.02 & 0.14 & 0.02 & & 0.03 & 0.03 & 0.22 & 0.02 & \\
\hline & $\mathbf{H} \times \mathbf{A}$ & & 0.06 & 0.02 & 0.18 & 0.05 & & 0.01 & 0.08 & 0.29 & 0.08 & \\
\hline & $\mathbf{Y} \times \mathbf{H} \times$ & & 0.03 & 0.04 & 0.23 & 0.03 & & 0.04 & 0.05 & 0.23 & 0.04 & \\
\hline
\end{tabular}




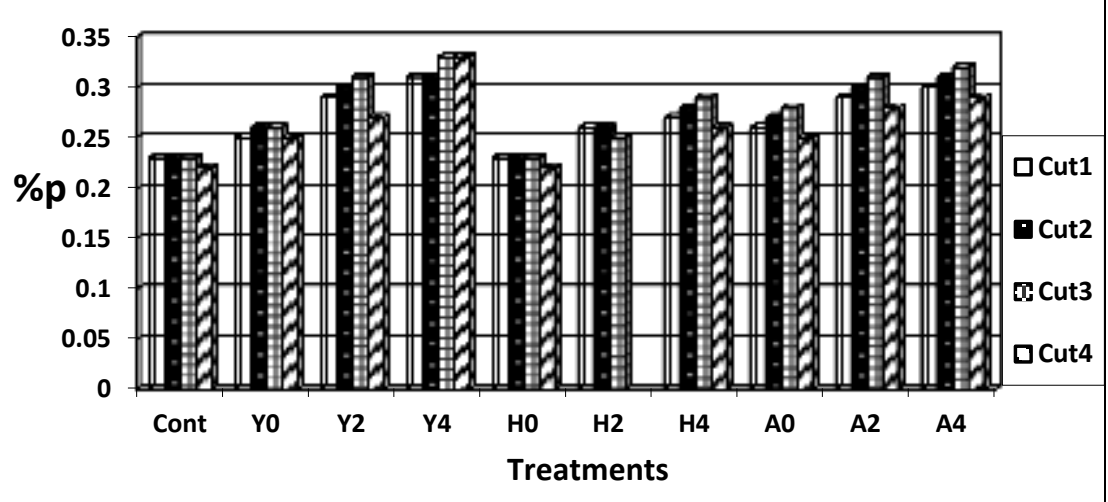

Fig (3) .Effect of the studied treatments on P\% of Egyptian clover through four cuts

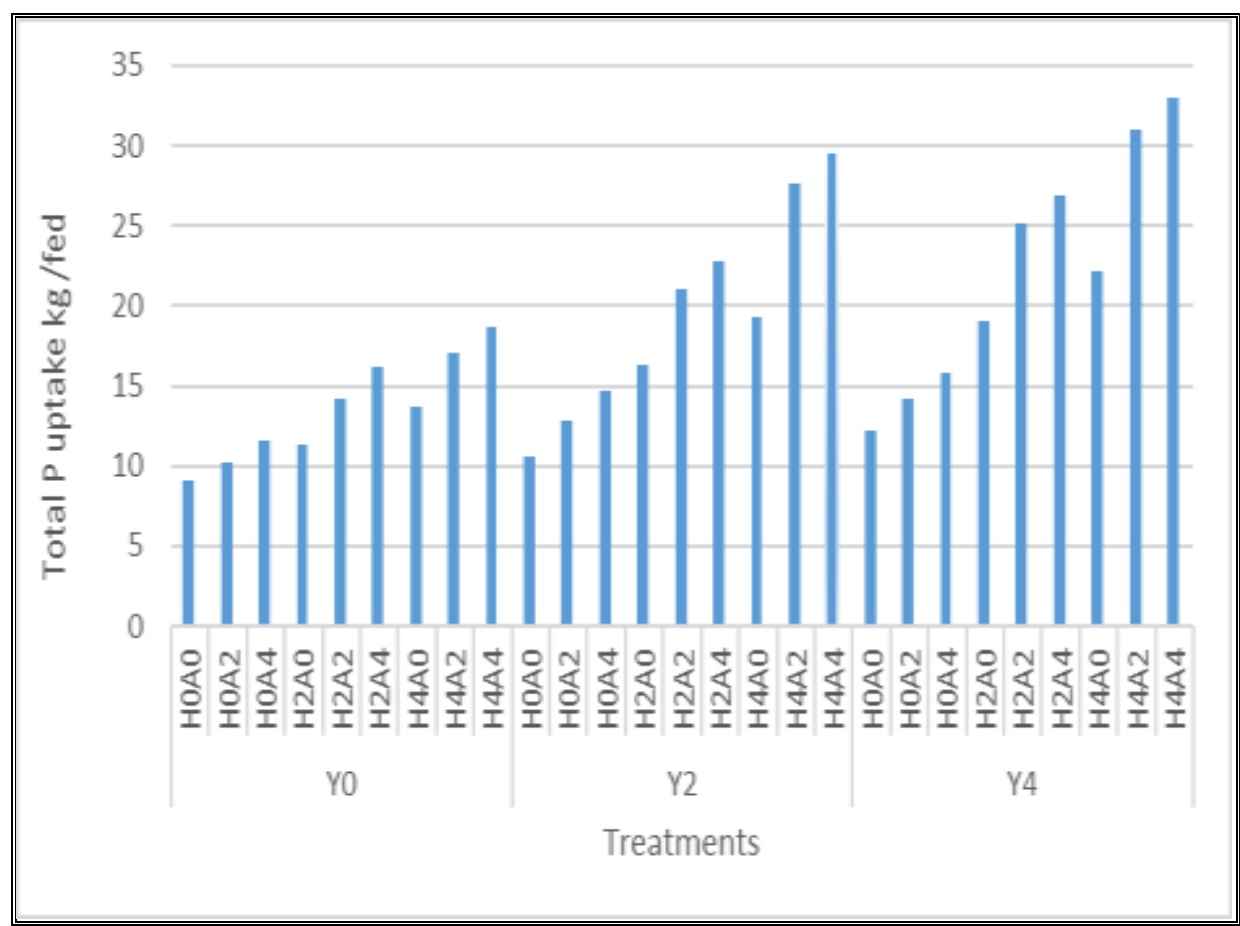

Fig (4) .Effect of the studied treatments on the accumulative $P$ uptake at whole season ( $\mathrm{kg} / \mathrm{fed}$.$) .$ 


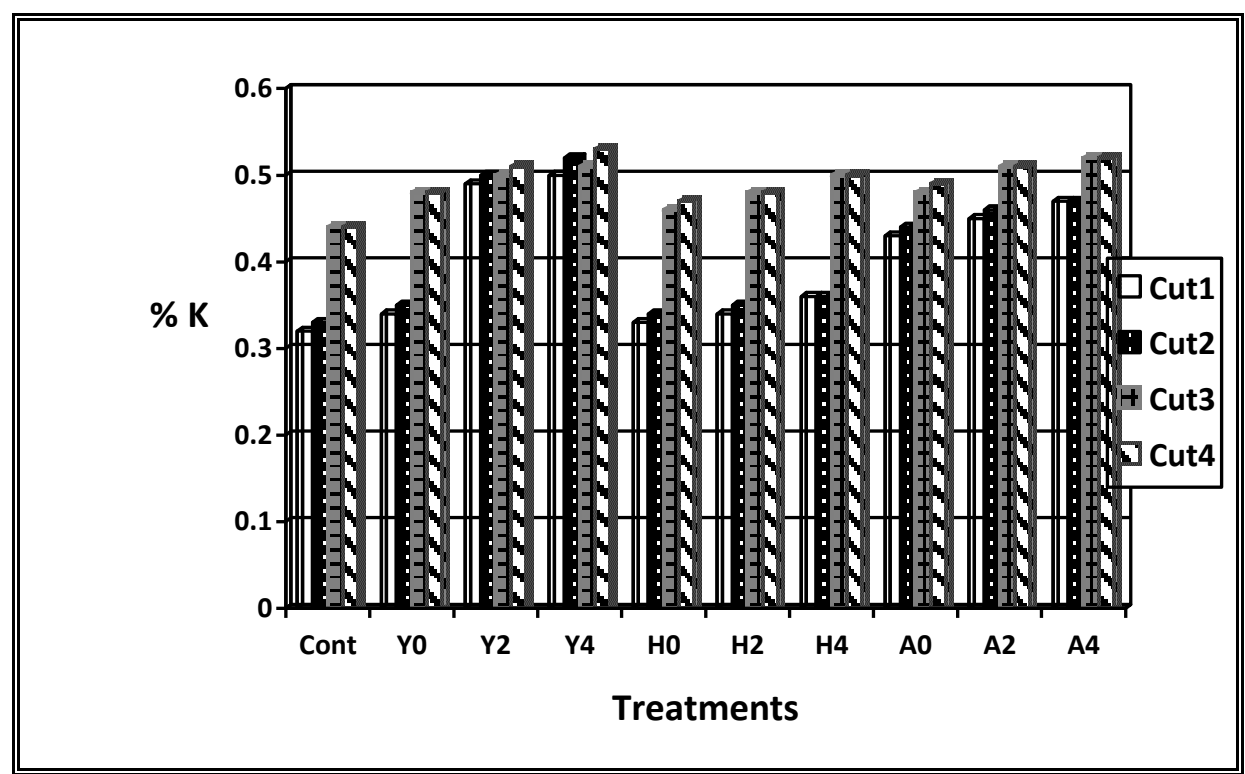

Fig (5) .Effect of the studied treatments on K\% of Egyptian clover through four cuts.

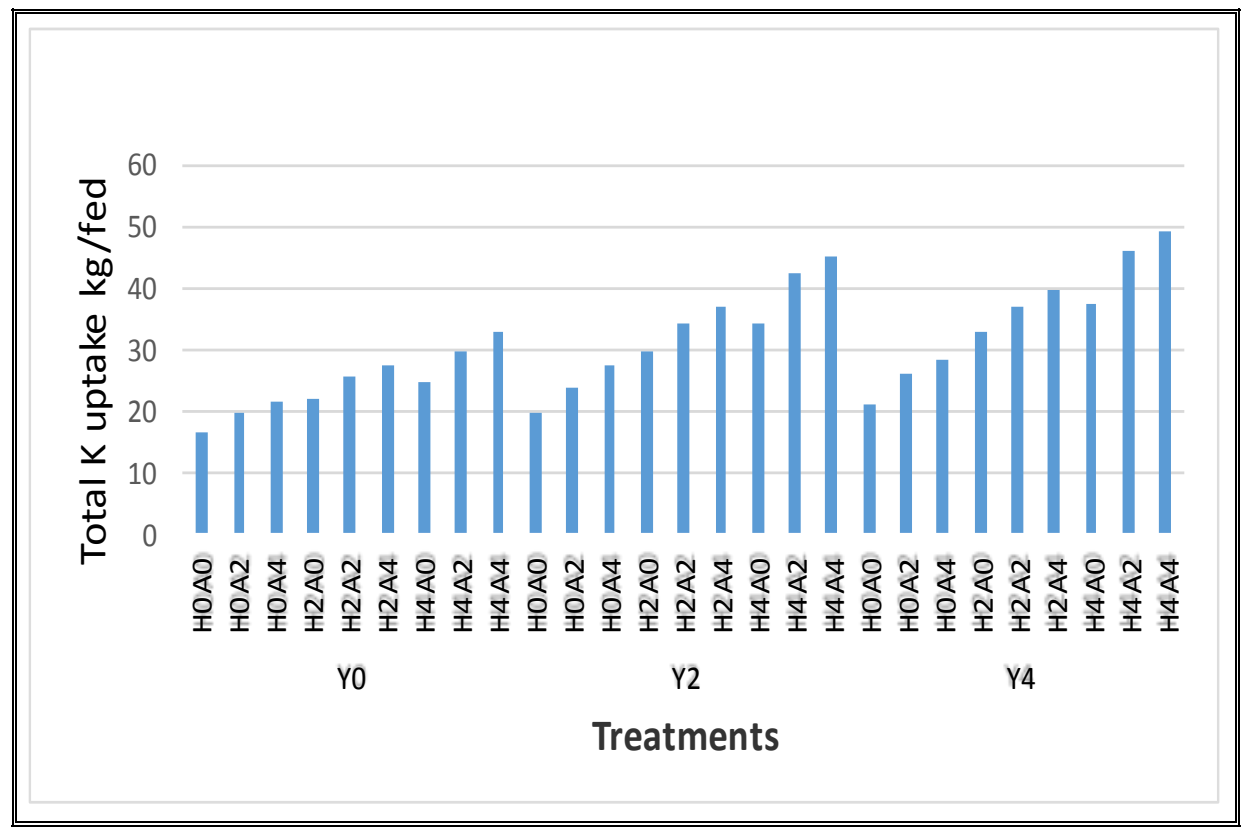

Fig (6). Effect of the studied treatments on accumulative $\mathrm{K}$ uptake at whole season (kg/fed.). 
The increases of concentration and uptake of nutrients studied may be due to role the natural applied growth promoters as active dry yeast , humic and amino acids even, individually or together as double or triple applications have benefit effects and their role in the activation of all vital processes which affect and improving the plant growth (Egyptian clover ) throughout the studied 4 cuts, as well as encourage the absorption of some essential nutrients such as (N, P and K) from soil and by then increased their concentrations and uptakes these results agreed with many investigators ,likewise , El-Nemer, (2012 ) , El -Hefny (2010) , Sultan et al., ( 2016 ), Abosedra et al., ( 2010) . and Hafez et al., ( 2020 )

\section{REFERENCES}

Abdel Nabi, H.M.A. ; K. Dawa ; E.I.E. Gamily and E. F.Y. Imryed (2014). Impact of mineral, organic and biofertilization on growth, yield and quality of cantaloupe. J. Plant Prod., Mansoura Uni., 5(11): 1777-1794.

Abo Sedera, F.A. ; A.A. Abd El-Latif,; L.A.A. Bader and S.M. Rezk (2010). Effect of NPK mineral fertilizer levels and foliar application with humic and amino acids on yield and quality of strawberry. Egypt J. Appl. Sci., 25:154-169.

Ahmed, A.A. ; M.M.H.A.E. Baky ; Y.I. Helmy and M.R. Shafeek (2013). Improvement of potato growth and productivity by application of bread yeast and manganese. J. of Appli. Sci. Research, 9(8): 4896-4906.

Akinremi, O.O. ; H.H. Janzen ; R.L. Lemke and F.J. Larney (2000). Response of canola, wheat and green beans to leonardite additions. Canadian J. of Soil Sci., 80(3): 437-443.

Asik, B.B. ; M.A. Turan,; H. Celik and A.V. Katkat (2009). Effects of Humic Substances on plant growth and mineral nutrients uptake of wheat (Triticum durum cv. Salihli) under conditions of salinity. Asian J. Crop Sci., 1:87-95.

Awad, El-M.M. ; A.M. Abd El-Hameed and Z.S. Shall (2007). Effect of glycine, lysine and nitrogen fertilizer rates on growth, yield and chemical composition of potato. J. Agric. Sci. Mansoura Univ., 32(10): $8541-8551$.

Chapman, H. D. and F. P. Pratt (1982). Methods of Analysis for soils, plants and waters". Dept. of soil. PI. Nutrition, Univ. of California, Davis, U.S.A., 670-681.

Chen, Y.; M.D. Nobili and T. Aviad, (2004). Stimulatory effect of humic substances on plant growth. In "Soil Organic Matter in 
Sustainable Agriculture” . (Eds F. Magdoff, R.R. Weil), 103130, Boca Raton, Fl.

El-Hefny, E. M. (2010). Effect of saline irrigation water and humic acid application on growth and productivity of two cultivars of cowpea (Vigna unguiculata L. Walp). Aust. J. Basic and Appl. Sci., 4: 6154-6168.

El-Nemr, M.A. ; M. El-Desuki ; A.M. El-Bassiony and Z.F. Fawzy (2012). Response of growth and yield of cucumber plants (Cucumis sativus L.) to different foliar applications of humic acid and bio- Stimulators. Australian J. of Basic and Applied Sci., 6(3): 630-637.

El-Shabasi, M.S. ; S.M. Mohamed and S.A. Mahfouz (2005). Effect of foliar spray with amino acids on growth, yield and chemical composition of garlic plants. The $6^{\text {th }}$ Arabian Conf. for Hort. Ismailia, Egypt.

El-Zohiri, S.S.M. and Y.M. Asfour (2009). Effect of some organic compounds on growth and productivity of some potato cultivars. Annals Agric. Sci. Moshtohor, 47(3):403-415.

Ghorbani, S.; H.R. Khazaei ; M. Kafi and M. Banayan Aval (2010). The effect of adding humic acid to irrigation water on yield and yield components of corn. J. A. Eco., 2:123-131.

Hafez, M.R. ; G.A. El-Desouky and F.A. EL- Azizy (2020) Improving Onion Productivity Grown in Siwa Oasis as Affected by Foliar Spray by K-Silicate and Fertigation by Humic and Amino Acids .Alex. Sci. Exch. J., 41 (4):573-581.

Karakurt, Y. ; H. Unlu ; H. Unlu and H. Padem (2009). The influence of foliar and soil fertilization of humic acid on yield and quality of pepper. Acta Agric. Scandinavica, Section B - Soil and Plant Science, 59(3): 233-237.

Karuppaiah, P. ; K. Manivonnar ; K. Sriramach ; M.V. Andrasakaron and G. Kuppusamy (2000). Responses of cucumber to foliar application of nutrients on light mine spoil. J. of the Indian Society of soil Sci., 49(1): 150 - 153.

Kowalczyk, K. and T. Zielony (2008). Effect Amino plant and Asahi on yield and quality of lettuce grown on Rockwool. Conf. of Bio stimulators in Modern Agric., 7-8 February, Warsaw, Poland.

Liu, Xing-quan ; H.Y. Chen ; N. Qin-xue and L.K. Seung (2008). Evaluation of the Role of mixed amino acids in nitrate uptake 
and assimilation in leafy radish by using $15 \mathrm{~N}$-labeled nitrate. Agric. Sci. CHN. 7(10):1196-1202.

Marzauk, Neama M. ; M.R. Shafeek ; Y.I. Helmy ; A.A. Ahmed and Magda A.F. Shalaby (2014). Effect of vitamin E and yeast extract foliar application on growth, pod yield and both green pod and seed yield of broad bean (Vicia faba L.) Middle East J. of Appli. Sci., 4(1): 61-67.

Perez, P.G. ; R. Zhang ; X. Wang ; J. Ye and D. Huang (2015). Characterization of the amino acid composition of soils under organic and conventional management after addition of different fertilizers. J. Soils and Sediments, 15(4): 890-901

Peterburgskei, A.V. (1968). "Hand Book of Agronomic Chemistry" Kolos publishing House, Moscow. (In Russian). 29-86.

Sanyal, D. ; R.J. Goos and A. Chatterjee (2018). Determining Symbiotic Nitrogen Fixation in Dry Bean Cultivars Using Ureide Method and Isotope Dilution Techniques. Communication in Soil Sci. and Plant Analysis, 49(16):2042-2052.

Shehata, S.A. ; Z. Fawzy and H. El-Ramady (2012). Response of cucumber plants to foliar application of chitosan and yeast under greenhouse conditions.Australian J. Basic and Appli. Sci., 6(4): 63-71.

Snedecor, G.W. and W.G. Cochran (1982). Statistical Methods. The Iowa State Univ., Press, Ames, Iowa, U.S.A.

Sultan, Fadia M.; N.A. Anton and F.A. Zahran (2016). Response of Egyptian Clover (Variety Fahl) to Foliar Spray with Potassium Humate, Fulvate as well as Amino Acids Mixture J.Soil Sci. and Agric.Eng., Mansoura Univ., 7(10): 739- 743.

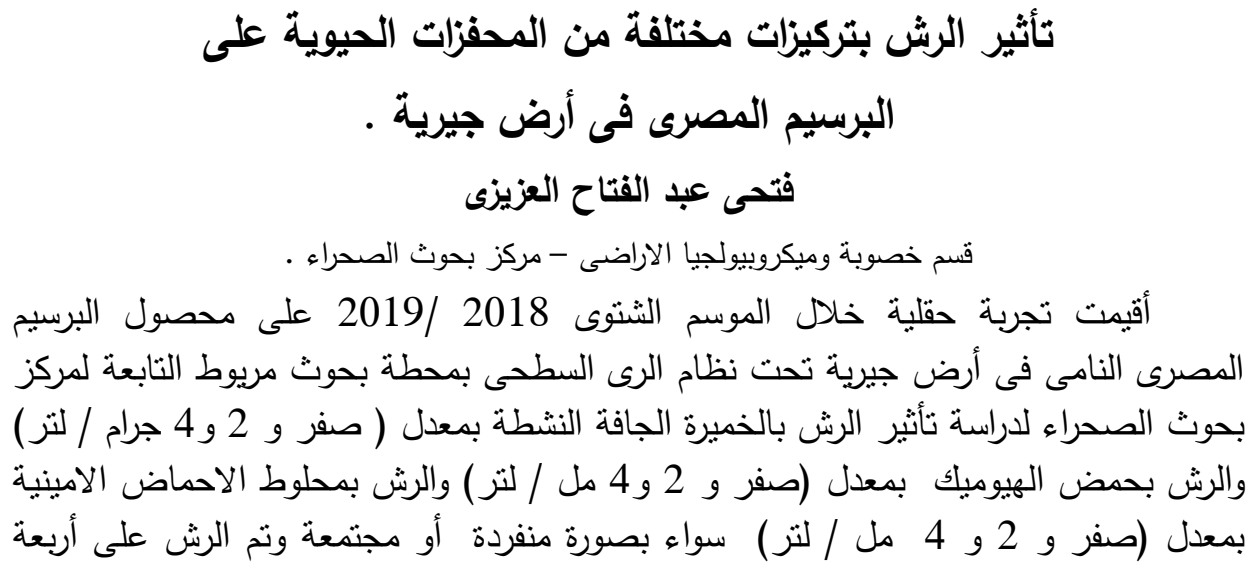




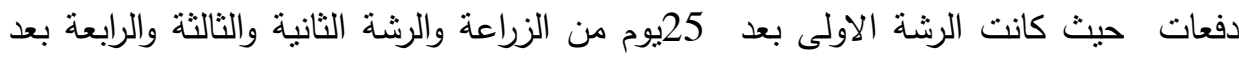

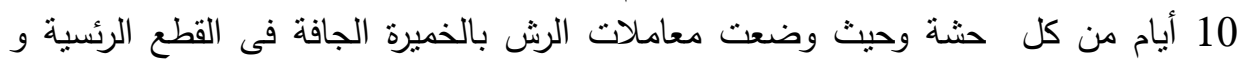

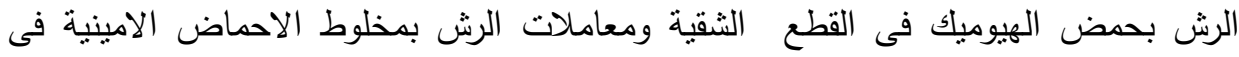

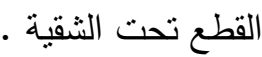

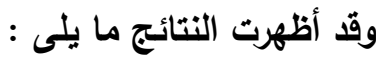

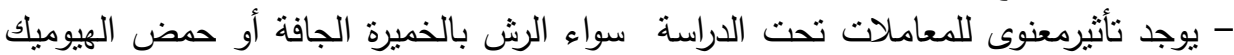

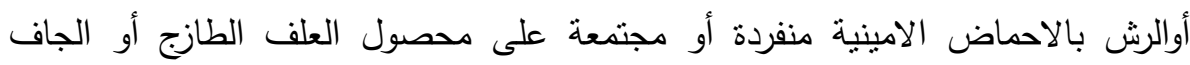

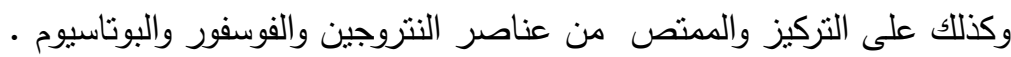

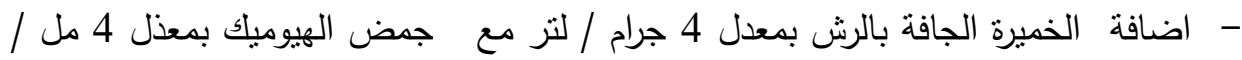

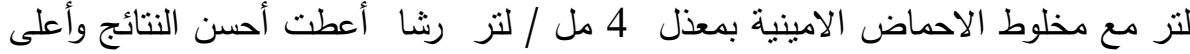

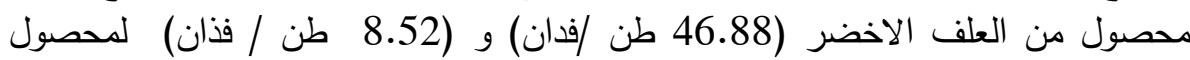

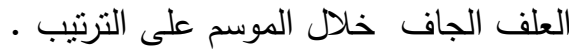

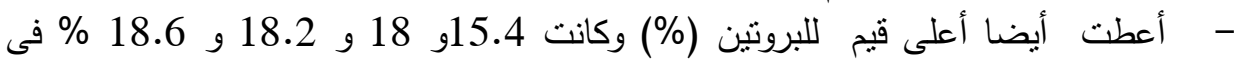

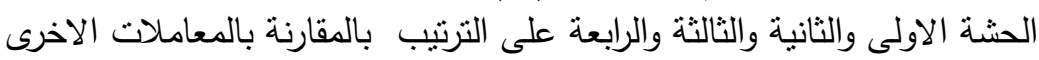
-وكذلك أعطت أعلى قيم للتركيز والممتصمن من عناصرالنتروجين والفسفور والبوتاسيوم تحت بلتئن

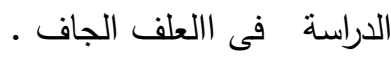

